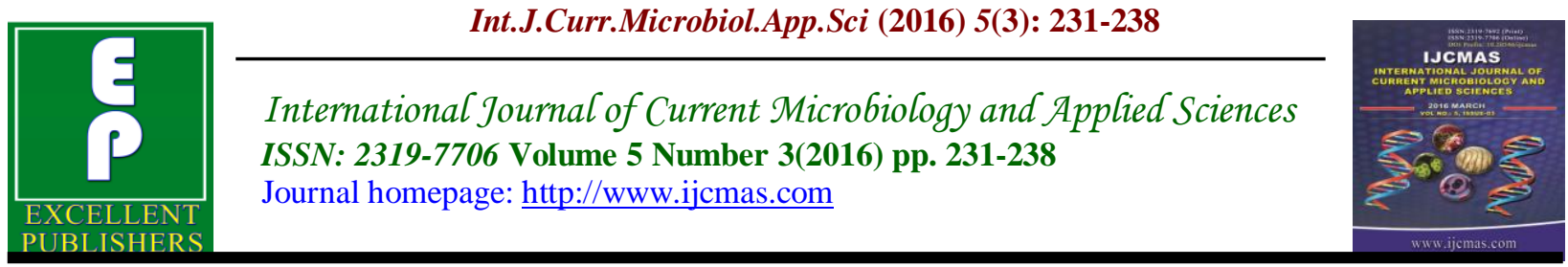

Original Research Article

http://dx.doi.org/10.20546/ijcmas.2016.503.028

\title{
Exercising Strategic Planning and its Impact on Human Resources Management
}

\author{
Faysal Ishag Adam Yousif ${ }^{1}$, Mohamed Ali Alsaoori ${ }^{2}$ and Ismail Mohamed Fangama ${ }^{3^{*}}$ \\ ${ }^{1}$ College of Graduate Studies, Peace Studies and Community Development, \\ Nyala University, Sudan \\ ${ }^{2}$ EINeelein University, Sudan \\ ${ }^{3}$ Sudan University of science and Technology, Sudan \\ *Corresponding author
}

\begin{tabular}{|c|c|}
\hline \multirow[b]{2}{*}{ Keywords } & A B S T R A C T \\
\hline & \multirow{4}{*}{$\begin{array}{l}\text { The present study aimed at investigating the strategic planning that is } \\
\text { adopted for managing human resources through the objectives that were set } \\
\text { out based on the institution's vision and mission, the researcher has adopted } \\
\text { the descriptive-analytical method for collecting research data, the data have } \\
\text { been reviewed, in this study the topic of strategic planning of human } \\
\text { resources, and its principles, its development as well as its competitive } \\
\text { feature have been explored. }\end{array}$} \\
\hline $\begin{array}{l}\text { Employees, } \\
\text { Planning, Strategic, } \\
\text { Training. }\end{array}$ & \\
\hline Article Info & \\
\hline $\begin{array}{l}\text { Accepted: } \\
\text { 15 February } 2016 \\
\text { Available Online: } \\
\text { 10, March } 2016\end{array}$ & \\
\hline
\end{tabular}

\section{Introduction}

Strategic planning is defined as (the actual planning constitutes prediction, what things will be in the future, and to get ready for things in the future). Planning has also been defined as what will be in the future regarding the elements of work needed for achieving objectives, and the readiness to address the hindrances, and to benefit from the potential positive aspects in the future in a particular period of time (Shawes, 1998). Strategic human resources planning (SHRP) is defined as one of activities, functions, and administrative practices that are performed by human resources in various types of organizations where by the organization's needs of human resources are estimated in terms of numbers, types and their skills in such a way that it can serve the organization's strategic plan.

Human resource planning is defined as estimation of the organization's needs of human resources that have specific skills and specializations in a particular period of time and devising the best method for meeting these requirements (Shawes, 1998).

The activities pertaining to Human resource planning serve a variety of objectives that are related to individuals, organization and the community, regarding an individual, it is possible to achieve the maxim of the right man in the right place through proper planning, an organization can achieve its 
integrity by ensuring that there is no shortage or surplus in human resources, and with respect to the community to achieve the full and sound exploitation of human resources, the organization should attain the ideal exploitation of the human resources. Human resource planning aims to answer the following questions: What are the quantity and quality of the required human resources?, How can we obtain these resources?, When should we obtain these resources? and Where do we make use of these resources?

Ahsour (1995) has mentioned that the task of the planning administration particularly the strategic planning of human resources is a man who is the basis of development and its ultimate goal. The notion of planning implies engaging in the future of the people economically, socially, culturally, and administratively. However, the strategic planning aims to confront the future so as to achieve specific goals. The significance of the strategic planning of human resources lies in its quest in drawing up short and long terms future plans so as to achieve the desired goals which are as follows: To recruit the highly qualified people from the labour market or from within the organization. Help to highlight the points of weaknesses and strength in the quality of the human resources' performance by determining the type of training that aims to boost the level of employees' performance. Help to improve the exploitation of human resources. Help to broaden the data base, and management information for the employees. Help to attain integrity between different human resources' programmes because the requirements' of planning works closely with the training planning.

\section{Strategic Administration and Human Recourse Development}

Currently, the state is concerned with boosting the level of productivity which in turn helps in pushing the wheel of economic development, improving the level of living standard, realizing high quality of life. In 1990, s there was growing concern about the human resources in various organizations that viewed it as the most important resources through which the desired goals could be achieved. As such Human resources is viewed as an important element of development, so the countries around the world have embarked on formulating comprehensive plan for human development, so it has become imperative for any organization to set out its general objectives, and these objectives are strongly related to the strategic planning which are the basis of long- term planning which in turn is responsible for the organization' success (Akaili, 2005).

\section{The Research Problem}

The organizations are faced by huge internal and external challenges such as (technological, economical, social, environmental...etc) these challenges affect the working environment, which require changes to be taken by the organization, the organization does operate within the existing environment, therefore, it affects and is affected by the changes taking place so it should not stay aloof, it should predict the potential changes and plan in advance so that it can address the challenges wisely. The administration of human resources management is the most affected by these changes simply because it is in charge of the activities related to the most important resources that are owned by the organization, it is always the first to be affected by the changes that occur in the external environment so it has become imperative for the organization to address these external challenges that affect the individuals and to get adapted to them. This was done by making some amendments to 
the existing policies and practices or adopting new policies and practices. Therefore, planning process is viewed as a global phenomenon nowadays; a lot of countries have paid more attention to planning, regarding it as a methodology and approach for resolving their problems, and an effective tool towards their development. If planning is viewed as a natural process in all developed countries but it is viewed as something of great significance to the developing countries because it helps these countries to fight backwardness so as to join the ranks of the developed nations particularly in the field of manpower (i.e. labour force).

The study has come up to highlight the following objectives:

1. The role of the strategic planning in administering human resources so that it can administer the changes that take place in the environment by adopting a method for handling these problems.

2. It also aimed to identify the principles of strategic planning for human resources, strategic management, development of human resources, and to explore the competitive feature of human resources.

\section{Hypotheses of the Study}

1. Any activity of the strategic planning for human resources serves varied goals of an individual, an organization, and the community.

2. The importance of strategic management for human resources helps to highlight the points of weaknesses and strength in the quality of human resources which in turn determine the type of
3. Training needed for boosting the employees' performance.

4. The strategic planning for human resources help in broadening the data base, and administrative information for employees.

5. The process of human resources planning is a strategic one.

6. Human resource strategy is part of the organization strategy.

7. One dimension of strategic management of human resources is ensuring the qualified cadres needed by the organization.

8. The importance of competitiveness lies in creating a competitive environment suitable for deploying the qualified human resources to be utilized.

\section{Methods of Data Collection}

The research data have been collected from the primary data that represented the following:

1. An interview was conducted with administrators, and others focusing on the role of the strategic planning in managing human resources.

2. A questionnaire was also administered to a group of employees in Nyala town, and the number of participants was (216). The questionnaire aimed to test the research hypotheses. The data were also collected from the secondary sources that represented: the references and periodicals that have tackled issue of strategic planning in administering the human resources which is regarded as vital for planning process that is 
necessary for the development any organization.

\section{Results and Discussion}

\section{Methods of Strategic Planning}

It has been reported that $35.2 \%$ of respondents answered' strongly agree, and $50.5 \%$ of them opted for agree. This clearly indicates that the administration of human resources has followed the method of Strategic Planning (Table 1).

\section{The Goals that are served by Strategic Planning}

Table (2) indicated that the strategic planning of human resources serve a variety of goals such as individual, organizational and societal ones. It has been reported that $32.9 \%$ of the participants have answered strongly agree, and $50.9 \%$ stated agree. And this answer has confirmed the first hypothesis that the strategic planning of human resources serves a variety of goals.

\section{The Significance of Strategic Planning}

Table (3) indicated that the participants' answers regarding whether Strategic Planning helps to show the points of strengths and weaknesses regarding the quality of human resources. It has been reported that $32.9 \%$ of the respondents' answers were strongly agree, and $40.7 \%$ answered agree.

\section{The Type of Employees' Training Aimed} to Boost their Performance is determined by Training Strategy.

Table (4) pointed out that the participants' statements were as follows: $41.2 \%$ of them answered strongly agree, $48.6 \%$ agree. This confirmed the second research hypothesis that the strategic planning helps highlight the points of strengths and weaknesses, and it specifies the type of training needed for boosting employees' performance.

Strategic Planning can Broaden the Data Base and Administrative Information of Employees

The participants have reported that $29.6 \%$ of them have answered strongly agree, and $52.8 \%$ of them agree, $9.3 \%$ were neutral, $2.8 \%$ disagree, $0.5 \%$ disagree strongly, $4.6 \%$ do not know. This has confirmed the third hypothesis which stated that strategic Planning can broaden the Data base and Administrative Information of Employees (Table 5).

\section{The Process of Human Resource Planning is a Strategic One}

The below table has pointed out that $19 \%$ of the respondents' answers were strongly agree, $45.4 \%$ agree, $11.6 \%$ neutral, $10.6 \%$ disagree, $3.2 \%$ disagree strongly, and $8 \%$ do not know.

\section{Human Resource Strategy is Part of the Firm's Strategy}

In table (7) the respondents' answers were as follows: $25.9 \%$ of them answered strongly agree, $51 \%$ answered agree, $6.9 \%$ neutral, $8.8 \%$ disagree, $2.3 \%$ disagree strongly, and $4.2 \%$ did not know. Respondents' answers in 5 and 6 confirmed the fourth research hypothesis: the human resource planning process is a strategic process, and Human Resource Strategy is part of the Firm's Strategy.

\section{Ensuring the Suitable and Qualified Human Element}

In the table below the respondents' answers concerning whether the strategic dimensions for the human resources can guarantee the 
suitable and qualified human element that is needed by the organization. The respondents' answers were as follows: $41.2 \%$ answered strongly agree, $46.8 \%$ agree, $6.9 \%$ neutral, $1.9 \%$ disagree, $0,5 \%$ strongly disagree, $3 \%$ did not know. The respondents' answers in this question confirmed the $6^{\text {Th }}$ hypothesis that is; the strategic dimensions for the human resources can guarantee the suitable and qualified human element that is needed by the organization.

Table.1 Methods of Strategic Planning

\begin{tabular}{|l|c|c|}
\hline \multicolumn{1}{|c|}{ Description } & Frequency & Percentage \\
\hline Strongly agree & 76 & 35.2 \\
\hline Agree & 109 & 50.5 \\
\hline Neutral & 17 & 7.9 \\
\hline Disagree & 6 & 2.8 \\
\hline Disagree strongly & 5 & 2.3 \\
\hline Don't know & 1 & 0.1 \\
\hline Missing system & 2 & 0.9 \\
\hline Total & 216 & 100 \\
\hline
\end{tabular}

Table.2 Strategic Planning of Human Resources Serve a Variety of Goals

\begin{tabular}{|l|c|c|}
\hline \multicolumn{1}{|c|}{ Description } & Frequency & Percentage \\
\hline Strongly agree & 71 & 32.9 \\
\hline Agree & 110 & 50.9 \\
\hline Neutral & 17 & 7.4 \\
\hline Disagree & 6 & 2.8 \\
\hline Disagree strongly & 5 & 2.3 \\
\hline Don’t know & 6 & 2.8 \\
\hline Missing system & 2 & 0.9 \\
\hline Total & 216 & 100 \\
\hline
\end{tabular}

Table.3 Significance of Strategic Planning in Highlighting the Points of Strengths and Weaknesses

\begin{tabular}{|l|c|c|}
\hline \multicolumn{1}{|c|}{ Description } & Frequency & Percentage \\
\hline Strongly agree & 71 & 32.9 \\
\hline Agree & 88 & 40.7 \\
\hline Neutral & 22 & 10.2 \\
\hline Disagree & 22 & 10 \\
\hline Disagree strongly & 5 & 2.3 \\
\hline Don't know & 6 & 2.8 \\
\hline Missing system & 2 & 0.9 \\
\hline Total & 216 & 100 \\
\hline
\end{tabular}


Table.4 Type of Employees Training Aimed to Boost their Performance is Determined by Training Strategy

\begin{tabular}{|l|c|c|}
\hline \multicolumn{1}{|c|}{ Description } & Frequency & Percentage \\
\hline Strongly agree & 89 & 41.2 \\
\hline Agree & 105 & 48.6 \\
\hline Neutral & 7 & 3.2 \\
\hline Disagree & 10 & 4.6 \\
\hline Disagree strongly & 2 & 0.9 \\
\hline Don't know & 1 & 0.5 \\
\hline Missing system & & 0.9 \\
\hline Total & 216 & 100 \\
\hline
\end{tabular}

Table.5 Strategic Planning can Broaden the Data Base and Administrative Information of Employees

\begin{tabular}{|l|c|c|}
\hline \multicolumn{1}{|c|}{ Description } & Frequency & Percentage \\
\hline Strongly agree & 64 & 29.6 \\
\hline Agree & 114 & 52.8 \\
\hline Neutral & 20 & 9.3 \\
\hline Disagree & 6 & 2.8 \\
\hline Disagree strongly & 1 & 0.5 \\
\hline Don't know & 10 & 4.5 \\
\hline Missing system & 1 & 0.5 \\
\hline Total & 216 & 100 \\
\hline
\end{tabular}

Table.6 The Process of Human Resource Planning is a Strategic One

\begin{tabular}{|l|c|c|}
\hline \multicolumn{1}{|c|}{ Description } & Frequency & Percentage \\
\hline Strongly agree & 41 & 19.0 \\
\hline Agree & 98 & 45.4 \\
\hline Neutral & 25 & 11.6 \\
\hline Disagree & 23 & 10.6 \\
\hline Disagree strongly & 5 & 2.3 \\
\hline Don't know & 17 & 7.9 \\
\hline Missing system & 7 & 3.2 \\
\hline Total & 216 & 100 \\
\hline
\end{tabular}


Table.7 Human Resource Strategy is Part of the Firm's Strategy

\begin{tabular}{|l|c|c|}
\hline \multicolumn{1}{|c|}{ Description } & Frequency & Percentage \\
\hline Strongly agree & 56 & 25.9 \\
\hline Agree & 109 & 50.5 \\
\hline Neutral & 15 & 6.9 \\
\hline Disagree & 19 & 8.8 \\
\hline Disagree strongly & 5 & 2.3 \\
\hline Don't know & 9 & 4.2 \\
\hline Missing system & 3 & 1.4 \\
\hline Total & 216 & 100 \\
\hline
\end{tabular}

Table.8 Ensuring the Suitable and Qualified Human Element

\begin{tabular}{|l|c|c|}
\hline \multicolumn{1}{|c|}{ Description } & Frequency & Percentage \\
\hline Strongly agree & 89 & 41.2 \\
\hline Agree & 99 & 45.8 \\
\hline Neutral & 15 & 6.9 \\
\hline Disagree & 4 & 1.9 \\
\hline Disagree strongly & 2 & 0.9 \\
\hline Don't know & 6 & 2.8 \\
\hline Missing system & 1 & 0.5 \\
\hline Total & 216 & 100 \\
\hline
\end{tabular}

Table.9 Competitiveness Creates Conducive Environment for Allocating Competent Human Resources

\begin{tabular}{|l|c|c|}
\hline \multicolumn{1}{|c|}{ Description } & Frequency & Percentage \\
\hline Strongly agree & 100 & 46.3 \\
\hline Agree & 87 & 40.3 \\
\hline Neutral & 19 & 8.8 \\
\hline Disagree & 3 & 1.4 \\
\hline Disagree strongly & 2 & 0.9 \\
\hline Don't know & 3 & 1.4 \\
\hline Missing system & 2 & 0,9 \\
\hline Total & 216 & 100 \\
\hline
\end{tabular}

\section{Competitiveness Creates Conducive Environment for Allocating Competent Human Resources}

The respondents' answers in the table below regarding the above statement pointed out that $46.3 \%$ of them answered strongly agree, $40.3 \%$ agree, $8.8 \%$ neutral, $1.4 \%$ strongly disagree, and said1.4\% did not know. The respondents' answers have confirmed the $7^{\text {th }}$ research hypothesis that Competitiveness of the Human Resources creates Conducive 
Environment for Allocating Competent so for utilizing them.

In conclusion, the task of human resource planning is viewed as one of the central tasks that the organizations should pay their attention to because it aimed to realize their visions and missions through adopting all the methods in the process of the strategic planning so that they can keep up pace with the recent developments.

\section{Recommendation}

The results have revealed the following recommendations:

1. Changing the role of human resource administration so as to boost its participate in the preparation and drawing up of strategic plans on the level of organization as a whole and its role should not be confined only to The execution and application of plans at the final stages.

2. The human resource administration should be a real partner in the preparation and application of the strategic plans on the level of organization and should play a leading role in the prediction of the changes and conditions that have impact on its performance to effectively manage the human resources.

3. The organization should have clear vision and mission, and should strive hard to achieve them in the future; the organization's employees should participate in the formulation of the strategic plans so that the process of planning should be realistic and objective.

4. Human resource development planning should be reviewed and it not be viewed as the training programmes' schedule and the preparation of the required budget. But it is the process of the organization needs of human resources such as being aware about the skills, trends, and to relate between them and the organization's goals in a practical way.

5. Adopting effective practices that are concerned with the measurement of investment revenues in the administrative training which in turn boost the human resource's inputs that are capable of formulating and achieving the overall goals of the organization.

\section{References}

Shawesh, M.N. 1998. Human Resource Administration, Dar el Shoruq for Distribution, Omman, Jordon.

Ashour, A.S. 1995. Human Resource Administration.University Printing Press, Alexandria University, Egypt.

Egali, O.W. 2005. Modern Human Resource Administration.Wail Printing Press., Omman,

\section{How to cite this article:}

Faysal Ishag Adam Yousif, Mohamed Ali Alsaoori and Ismail Mohamed Fangama. 2016. Exercising Strategic Planning and its Impact on Human Resources Management. Int.J.Curr.Microbiol.App.Sci. 5(3): 231-238. doi: http://dx.doi.org/10.20546/ijcmas.2016.503.028 